\section{Explaining the complexity relationship of CSR and financial performance using neo-institutional theory}

Relationship of CSR and financial performance

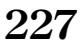

\author{
Golrida Karyawati P \\ Department of Accounting, Universitas Prasetiya Mulya, Jakarta Selatan, \\ Indonesia, and \\ Bambang Subroto, Sutrisno T and Erwin Saraswati \\ Department of Accounting, Brawijaya University, Malang, Indonesia
}

Received 29 October 2019 Revised 15 January 2020 19 February 2020

Accepted 20 February 2020

\begin{abstract}
Purpose - This study aims to prove the complexity of the relationship between CSR and financial performance (FP) and to decompose the complexity of the relationship using neo-institutional theory. Design/methodology/approach - This research employs a meta-analysis that integrates 55 various contexts studied between 1998 and 2017 using correlation coefficient as the effect size.

Findings - This study proves that the nature of the relationship between CSR and FP is complex and suggests that the analysis of the relationship between the two variables includes institutional factors to produce generalizable conclusions. Country characteristics, forms and dimensions of CSR, CSR measurements and FP measurements explain the complexity of the relationship between CSR and FP.

Research limitations/implications - Future research is expected to include industry characteristics and the corporate governance model in the analysis of the relationship between CSR and FP. Differences in industry characteristics affect the selection of CSR forms and dimensions, bringing it the potential to influence the relationship between CSR and FP. The corporate governance model adopted by developing countries and developed countries also has the potential to be an institutional factor to influence the relationship between CSR and FP.

Originality/value - This research proves that the complexity of the relationship between CSR and FP is nature given. This research explores the factors causing the complexity of the relationship using neoinstitutional theory, which, to the author's knowledge, has not been done by other researchers.
\end{abstract}

Keywords CSR, Financial performance (FP), Neo-institutional theory, Country characteristics, CSR forms and dimensions, CSR measurements, FP measurements

Paper type Research paper

\section{Introduction}

According to Golrida et al. (2018), the relationship between corporate social responsibility (CSR) and financial performance (FP) is very complex, because CSR practices are contextual and inherent in the institutions in which CSR is conducted. Therefore, individual testing of the relationship between CSR and FP will produce contextual conclusions and lack of generalization. CSR practices depend on the environment (Goll and Rasheed, 2004) through economic, legal, social, cultural and other institutional factors. The diversity of institutional characteristics leads to the complexity of CSR definitions and finally, various CSR measurements. The dynamics of institutional characteristics lead to an increasingly complex relationship between CSR and FP

(C) Golrida Karyawati P, Bambang Subroto, Sutrisno T and Erwin Saraswati. Published in Journal of Asian Business and Economic Studies. Published by Emerald Publishing Limited. This article is published under the Creative Commons Attribution (CC BY 4.0) licence. Anyone may reproduce, distribute, translate and create derivative works of this article (for both commercial and non-commercial purposes), subject to full attribution to the original publication and authors. The full terms of this licence may be seen at http://creativecommons.org/licences/by/4.0/legalcode

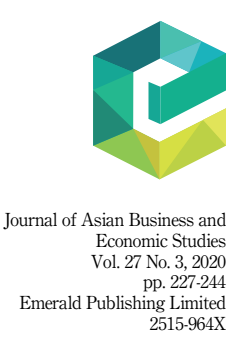

DOI 10.1108/JABES-10-2019-0106 
JABES 27,3

228
(Park and Ghauri, 2015). Macdonald and Maher (2013) stated that the relationship testing between CSR and FP is laden with limitations of methods. The complex relationship between CSR and FP will better be analyzed through multisetting research, such as meta-analysis.

A meta-analysis conducted by Orlitzky et al. (2003) and Allouche and Laroche (2005) reveals that the relationship between CSR and FP is very heterogeneous. These findings refer to the complexity of the relationship between CSR and FP. Namazi and Namazi (2016) state that the nature of complex business will be more transparently captured by considering moderation variables.

Stakeholder and legitimacy theories suggest a positive relationship between CSR and FP. However, the two theories do not disclose the process through which CSR influences FP, as the process reveals the complexity relationship of CSR and FP. New institutional theory proposes institutional factors that explain the complexity process of CSR and FP relationships. Using neo-institutional theory, this study examines the complexity of the relationship between CSR and FP and analyzes the institutional factors that cause the complexity of relations between the two variables. To overcome the weakness of individual testing that tends to produce high contextual conclusions as well as to gain a comprehensive picture of the relationship between CSR and FP, this study employs a meta-analysis that integrates research from various contexts.

This study maps 55 studies on the relationship between CSR and FP using the data from 1998 to 2017. The results of the analysis prove a positive relationship between CSR and FP, but the relationship is very heterogeneous, which indicates the complexity of the relations between the two variables. This study revealed that country-level institutional factors caused the complexity of the relationship between CSR and FP.

\section{Literature review}

\subsection{Neo-institutional theory}

Neo-institutional theory explains institutional changes that occur systematically, uniform (Dacin et al., 2002), structured or institutionally constructed (Clemens and Cook, 1999), so that the behaviors or characters in an organization are homogeneous or resemble one another (Meyer and Rowan, 1977). The formation of homogeneous characters in an organization is called isomorphism. Institutional isomorphism is carried out through mimetic, coercive and normative forces (DiMaggio and Powel, 1991).

Mimetic isomorphism occurs due to pressure to copy the forms and actions of other organizations, especially those that have similar characteristics to the company. Mimetic isomorphism often occurs under conditions of uncertainty, in which each individual's tendency is to reduce the risk of uncertainty by acting in reference to actions taken by individuals in general or certain individuals who are considered the most representative. Coercive isomorphism occurs because of pressure from outside parties (e.g. Government, regulations) to take certain actions as intended. Normative isomorphism occurs because of the actions of organizations to adopt certain systems or standards with the aim of getting recognition or certification from certain professional institutions. Isomorphism can take place if there is legitimacy and institutional support (Deephouse and Carter, 2005).

The neo-institutional theory explains the differences in the institutionalization process according to institutional factors. Neo-institutional theory can also be used to explain the complexity of CSR characteristics by revealing the process of how the boundaries between company and social are constructed (Brammer et al., 2012). According to neo-institutional theory, various forces influence organizations in adopting CSR practices (Fernando and Lawrence, 2014). Companies that have strong economic institutions, for example, have a greater ability to practice CSR. Regulations and laws force companies to carry out CSR activities. Historical factors influence the way companies are involved in CSR activities. 
Neo-institutional theory has been used to analyze CSR practice trends in various countries (Baughn et al., 2007). Countries that have similar institutional factors tend to share the same CSR practices through mimetic isomorphism. Companies tend to be more active in certain CSR activities if there are strong regulations and law enforcement for CSR activities through normative and coercive isomorphism. Husted and Allen (2006) found that multinational companies (MNCs) adopt the similar CSR practices wherever they operate. MNCs, for example, tend to only follow CSR practices that are in line with parent companies, which are located in developed countries compared to developing CSR strategies, which are appropriate to the country where the subsidiary is located.

\subsection{Hypothesis development}

Various theories predict a positive relationship between CSR and FP, such as stakeholder theory (Jones, 1995) and legitimacy theory (Zheng et al., 2014; Deephouse and Carter, 2005). Good CSR simplifies the relationship between a company and its stakeholder. CSR issues can be managed to generate profit for a company (Jones, 1995). If a company communicates its CSR well, it can improve the financial performance of the organization (Rettab et al., 2009). Even if companies spend a lot of resources to engage in CSR, market equality will compensate for the cost of CSR with profits (McWilliams and Siegel, 2001).

Although previous research presented inconsistent results regarding the relationship between CSR and FP, Orlitzky et al. (2003) and Allouche and Laroche (2005) found that, in general, the relationship between CSR and FP is positive. Galant and Cadez (2017) explained that a positive relationship between CSR and FP occurs when CSR is managed properly. Even though some CSR activities incur additional expenses, these expenses will not deteriorate profitability (Alexander and Buchholz, 1978). Instead, if CSR is managed properly, it will increase stakeholder satisfaction, which ultimately leads to an increase in FP (Aver and Cadez, 2009)

\section{H1. CSR has a positive effect on FP}

Previous research supported the claim that institutional factors influence CSR practices on the country level (Husted and Allen, 2006; Baughn et al., 2007; Wiig and Koldstat, 2010). The strength of the CSR relationship with FP is influenced by a country's institutional factors (Golrida et al., 2018; Li et al., 2010). Namazi and Namazi (2016) argued that a direct model of the relationship between CSR and FP is neither realistic nor complete. The true relationship between CSR and FP will be revealed when critical moderating variables are inserted in the model. Moderation indicates that the magnitude of the antecedent's influence (CSR) on company results (FP) depends on contingency factors such as the environment (Aguinis et al., 2017).

Neo-institutional theory suggests institutional factors as moderating variables. CSR practices are not separate from country-level factors (Golrida et al., 2018; Li et al., 2010). Misrah and Suar (2010) proved the relevance and importance of the country-level context in analyzing the relationship between CSR and FP. The institutional characteristics of CSR practices are generally grouped into practices in developed countries and practices in developing countries. These groupings produce comparable analyses. Previous research has also used this categorization (Beddewela and Herzig, 2013; Baughn et al., 2007).

\section{H2. Country characteristics moderate the relationship between CSR and FP}

The isomorphism that occurs in the diversity of country characteristics causes various forms and dimensions of CSR, according to the company's strategy (Halme and Laurila, 2009). The form and dimensions of CSR have come to the attention of previous researchers. Previous research on operationalized CSR has used various dimensions (e.g. Inoue and Lee, 2011). 
JABES 27,3

The dimensions of economics and labor are considered to be areas of fundamental responsibility (Carroll, 1979). The dimensions of social, environmental and corporate governance (CG) must be addressed to maintain business continuity. CG issues have attracted public attention with the unfolding of various corporate scandals. Philanthropic activities are effective in improving the company's reputation (Zheng et al., 2014; Godfrey, 2005). Inoue and Lee (2011) revealed that each form and dimension of CSR have a differential effect on FP. Hypothesis 3 is stated as follows:

\section{H3. CSR forms and dimensions moderate the relationship between CSR and FP}

The complex nature of CSR has an impact on its measurement. Various definitions of CSR lead to various CSR measurements (Grigoris, 2016; Galant and Cadez, 2017). CSR measurement causes an inconsistent relationship between CSR and FP (Griffin and Mahon, 1997).

Orlitzky et al. (2003) developed four CSR measurement strategies: content analysis, reputation, social audit and the value principle strategy. Content analysis strategy measures CSR based on a company's CSR disclosures. The weakness of content analysis strategy is the high subjectivity of the researcher due to different assessment standards. Reputation strategies measure CSR based on the assessment of independent institutions; therefore, this strategy is seen as objective and reliable. The result of an assessment of a reputation strategy can be a rating or an assessment score as performed by Wang and Qian (2011).

Social audit strategy is a measurement strategy based on a systematic assesment of CSR implementation, such as philanthropic activities and environmental programs, carried out by a third party. Social audit strategies generally refer to the monetary value of CSR implementations, as done by Hogan et al. (2014), Muller and Kräussl (2011) and Kanwal et al. (2013). The weakness of the social audit strategy is the subjectivity of its implementation, because the scope of the assessment is too broad. Principle and social performance strategies are rarely used by previous researchers, because they are difficult to implement and very subjective.

In fact, studies that use the same measurement strategy also vary greatly in measurement techniques. With the increasing number of studies on CSR, currently many researchers conduct surveys to measure CSR in order to be more objective and reliable, as was done by Misrah and Suar (2010). Survey strategy is done by designing questionnaires and distributing them to intended respondents. According to Wolfe and Aupperle (1991), CSR practices cannot be measured using a single approach. The fourth hypothesis is as follows:

\section{H4. CSR measurements moderate the relationship between CSR and FP}

When FP is seen as an impact of CSR practices (Peloza, 2009), various FP measurements are also unavoidable conditions, because CSR practices are very contextual. Galant and Cadez (2017) state that there is no perfect FP measurement. The best FP measurement is the measurement that best suits the situation, challenges and objectives of CSR (Peloza, 2009). Galant and Cadez (2017) state that the selection bias of CSR and FP measurements can influence the nature of the CSR-CFP relationship.

In general, researchers classify FP measurement strategies into accounting performance and market performance strategies. Accounting performance strategy considers financial statement information, such as return on assets (ROA), return on equity (ROE) and earning per share (EPS). Market-based performance strategy generally uses information about stock prices or stock returns. Previous studies also used a combination of market and accounting measurement strategies, such as Tobin's q and economic value added (EVA) conducted by Galant and Cadez (2017). Orlitzky et al. (2003) mapped FP measurements based on survey perception measurements. The fifth hypothesis is as follows:

H5. FP measurements moderate the relationship between CSR and FP 


\section{Research methods}

This study aims to prove the complexity of the relationship between CSR and FP. To overcome the weakness of individual testing that tends to produce high contextual conclusions as well as to get a comprehensive picture of the relationship between CSR and FP, this research employed a meta-analysis.

The sample of this research includes previous empirical studies of the relationship between CSR and FP using the 1998-2017 data period.

Since the focus of this investigation is business improvement, the sample of this research comes only from studies that treat CSR as an independent variable and FP as the dependent variable. Sample searches were conducted on digital libraries such as JSTOR, ScienceDirect and ProQuest. Since the focus of the meta-analysis is the diversity of research contexts, limiting the sample to only published journals introduces publication bias (Finckh and Tramer, 2008), which reduces the diversity of the research contexts. Therefore, this study also searched for other manuscripts, such as proceedings and working papers on Google.

Sample screening is performed using the keywords "CSR" and "Financial Performance". In the beginning, filtering of samples was carried out on the manuscript abstract. Manuscripts that state the keywords "CSR" and "Financial performance" are stored. Subsequent screenings, manuscripts that present qualitative research, those that do not include correlation coefficients, studies that treat CSR as the dependent variable or manuscripts that lack complete data such as sample size or year data were excluded from the sample. Finally, 55 studies were selected as research samples.

\subsection{Meta-analysis}

The meta-analysis in this study measures the magnitude of the relationship between CSR and FP using an effect size, which is a correlation coefficient $(r)$. If a previous study did not report $r$ but reported the results of a $t$-test, then the $t$-test value is transformed to $(r)$ as follows:

$$
r=\sqrt{t^{2} /\left(t^{2}+\mathrm{df}\right)}
$$

where $\mathrm{d} f$ is degrees of freedom

If the independent variable of a study consists of more than one CSR proxy, with only one FP proxy, the study correlation coefficient $(r)$ is the sum of all its correlation coefficients. If the dependent variable from the previous study consists of more than one FP proxy, the correlation coefficient $(r)$ of this study is the sum of all correlation coefficients divided by the number of its FP proxies. Once the $r$ statistic is obtained for each study, the population mean correlation is estimated by calculating the mean correlation coefficient $(\breve{r})$, weighted by the sample size $(\mathrm{Ni})$ for the collection of $i$ studes under review.

$$
\check{r}=\sum\left(N_{i} r_{i}\right) / \sum N_{i}
$$

where $\mathrm{Ni}=$ Number of observations

95\% confidence interval estimates are used to assess the significance of the relationship between CSR and FP. The population correlation coefficient (r) mean value and the SD are used to construct a confidence interval. SD is derived from population variance ( $\left.\mathrm{sp}^{2}\right)$. The best estimate of the population variance is the observed variance $\left(\mathrm{Sr}^{2}\right)$ minus the estimated sampling error variance $\left(\mathrm{Se}^{2}\right)$. The calculation of the observed variance $\left(\mathrm{sr}^{2}\right)$ among all individual correlation coefficients across studies is as follows:

$$
\mathrm{Sr}^{2}=\sum N_{i}\left(r_{i}-\check{r}\right) / \sum N_{i}
$$

Relationship of CSR and financial performance 
JABES 27,3

The formula for estimating the variance of sampling error $\left(\mathrm{se}^{2}\right)$ is:

$$
\mathrm{Se}^{2}=\left(1-r^{2}\right)^{2} K / \sum N_{i}
$$

where $K$ : Number of previous studies

Unbiased estimate of the population variance $\left(\mathrm{Sp}^{2}\right)$ is:

$$
\mathrm{Sp}^{2}=\mathrm{Sr}^{2}-\mathrm{Se}^{2}
$$

The relationship between CSR and FP is significant if the mean correlation value is within the confidence interval (CONF).

$$
r-(\mathrm{Sp} \times 1.96) \geq \check{r} \leq \check{r}+(\mathrm{Sp} \times 1.96)
$$

\subsection{Analysis of moderating effects}

The complexity of the relationship between CSR and FP in this meta-analysis study is shown through the heterogeneity of the relationship between the two variables. Heterogeneous relationships indicate the existence of moderating variables that explain the complexity of the relationship of the intended variable (Namazi and Namazi, 2016). Ahmed and Courtis (1999) stated that if at least $75 \%$ of the observed variance across the studies can be explained by the error variance, then the relationship is considered unmoderated and homogeneous (Ahmed and Courtis, 1999).

More accurately stated, this study also refers to the Chi-square test by Hunter and Schmidt (1990), using the formula as follows:

$$
x_{k-1}^{2}=\frac{N}{\left(1-r^{2}\right)} S_{r}^{2}
$$

where k: number of studies

If the calculated Chi-square value is higher than the Chi-square table value, the relationship between CSR and FP is heterogeneous. Consequently, a subgroup analysis is needed to reduce the heterogeneity of the relationships.

\section{Result}

\subsection{An aggregate meta-analysis}

There are 55 studies that meet the sample criteria as presented in Appendix 1. The accumulated correlation coefficient data and the number of observations $(n)$ of each study determine the effect size of all samples, as presented in Appendix 1. Aggregate testing integrates all correlation coefficients of the relationship between CSR FP from the 55 various studies. Analysis of the relationship between CSR and FP will produce conclusions that have broad generalizability if the relationship remains significant in all measurement settings, forms, dimensions and other contexts.

Table 1 provides the results of the aggregate analysis of the 55 studies. The mean correlation coefficient of the aggregate analysis is 0.2477 . At the $95 \%$ confidence level, the mean correlation is within the confidence interval of $0.0139-0.4815$. Hence, it can be concluded that the mean correlation value is significant. Thus, the first hypothesis is proven, because the results of the analysis prove a positive relationship between CSR and FP.

Further analysis shows that the relationship between CSR and FP is very heterogeneous. Only $12.71 \%$ of the observation variance is explained by the error variance. This indicates a moderating variable between the relationship between CSR and FP. Heterogeneity testing of 


\begin{tabular}{|c|c|c|c|}
\hline No & Description & Value & Relationship of \\
\hline 1 & Number of study $(K)$ & 55 & financial \\
\hline 2 & Observation $(N)$ & 11.090 & \\
\hline 3 & Number of correlation $(r)$ reported & 355 & pertormance \\
\hline 4 & Mean correlation $(\check{r})$ & 0.2477 & \\
\hline 5 & $95 \%$ confidence interval - minimum & 0.0139 & \\
\hline 6 & $95 \%$ confidence interval - maximum & 0.4815 & 233 \\
\hline 7 & Percentage variance explained $\left(\mathrm{Se}^{2} / \mathrm{sr}^{2}\right)$ & $12.71 \%$ & \\
\hline 8 & Chi-square calculated value & 432.6451 & Tab \\
\hline 9 & Chi-square table value & 72.153 & Aggregate analysis \\
\hline
\end{tabular}

the relationship between CSR and FP was also carried out by comparing the Chi-square calculated value and the Chi-square table value. The Chi-square calculated value (i.e. 432.6451) presented in Table 1 shows a much higher value than the Chi-square table value (i.e. 72.153). This confirms the heterogeneity of the relationship between CSR and FP. Thus, a subgroup analysis is needed to decompose the complexity of the relationship.

\subsection{Subgroup analysis based on country characteristics}

To prove the second hypothesis, this study employs subgroup analysis for two groups: developed and developing countries (Table 2). However, of the 55 sample analyses, only 38 studies stated the origin of the data, while 17 studies focused more on data sources such as KLD and others. Of the 38 studies that mentioned the country of origin of the data, 18 studies were conducted in developing countries and 20 studies conducted in developed countries as presented in Table 2.

Subgroup analyses in both the developed and developing country groups show different results. The studies in the developed country show a significant positive mean correlation $(\check{r})$ of 0.2858 , with an interval between 0.1808 and 0.3909 . However, the relationship between CSR and FP in developing countries is not significant, because the mean correlation $(\check{r})$ of developing countries falls between negative and positive confidence intervals $(-0.0719$ to 0.5320). Different findings between developed and developing countries show that country characteristics strengthen and weaken the relationship between CSR and FP. These results prove that country characteristics moderate the relationship between CSR and FP; thus, hypothesis 2 is proven.

Subgroup analysis based on country characteristics still shows a heterogeneous relationship between CSR and FP. The observed variance had a low explanatory power of no more than $30 \%$ in the two subgroups (Table 2). The Chi-square calculated value is higher than the Chi-square table value in both developed and developing countries. This finding is a

\begin{tabular}{lcc}
\hline Description & Developing & Developed \\
\hline Number of study $(K)$ & 18 & 20 \\
Number of correlation $(r)$ & 88 & 132 \\
Observation $(N)$ & 3.483 & 4.143 \\
Mean correlation $(\check{r})$ & 0.2301 & 0.2858 \\
Min-confidence interval (MinConf) & -0.0719 & 0.1808 \\
Max-confidence interval (MaxConf) & 0.5320 & 0.3909 \\
Observed variance explained $\left(\mathrm{Se}^{2} / \mathrm{sr}^{2}\right)$ & $9.39 \%$ & $29.67 \%$ \\
Chi-square calculated value & 191.6057 & 67.4123 \\
Chi-square table value & 27.587 & 30.144
\end{tabular}

Table 2.

Subgroup analysis country characteristics 
JABES 27,3

\section{4}

strong indication that there are still other moderating variables in the relationship between CSR and FP.

\subsection{Subgroup analysis - CSR forms and dimensions}

The subgroup analysis based on the forms and dimensions maps seven CSR forms and dimensions as presented in Table 3: CG, product, diversity, labor, environment, social and philanthropic activities. The subgroup analysis shows that only CG and philanthropy have a positive relationship between CSR and FP. The mean correlation of CG (0.1375) with a confidence interval between 0.0968 and 0.1782 is significant. The philanthropic mean correlation (0.1946) is also significant, because its value is between the confidence interval 0.1806 and 0.2087. Meanwhile, subgroup analyses of other forms and dimensions (i.e. products, diversity, labor, environment and social) do not show a significant relationship between CSR and FP because the confidence interval on each of the five forms and dimensions had a negative value. Thus, the third hypothesis is proven. CSR forms and dimensions moderate the relationship between CSR and FP.

Further testing found that the relationship between CSR and FP was homogeneous in four forms and dimensions: CG, product, diversity and philanthropy. The Chi-square calculated value for the four forms and dimensions is lower than the value of the Chi-square table value. However, the relationship between CSR and FP for the three dimensions (i.e. environment, labor and social) is very heterogeneous as the Chi-square calculated value of the dimensions is much greater than the Chi-square table value.

Highly heterogeneous results indicate further subgroup analysis on three dimensions to increase the homogeneity of the relationship between CSR and FP. A further analysis was conducted by subgrouping the three forms and dimensions in developing and developed countries (Table 4). Further subgroup only results in a homogeneous relationship in developing countries.

\begin{tabular}{|c|c|c|c|c|c|c|c|}
\hline Description & $\mathrm{CG}$ & Product & Diversity & Labor & Env & Social & Philant \\
\hline$K$ & 4 & 7 & 6 & 16 & 19 & 16 & 6 \\
\hline$N$ & 1201 & 1201 & 907 & 2.794 & 3602 & 3185 & 535 \\
\hline$\check{r}$ & 0.1375 & 0.0124 & -0.0047 & 0.1449 & 0.1171 & 0.1766 & 0.1946 \\
\hline MinConf & 0.0968 & -0.0029 & -0.0939 & -0.0545 & -0.0766 & -0.0295 & 0.1806 \\
\hline MaxConf & 0.1782 & 0.0278 & 0.0844 & 0.3442 & 0.3108 & 0.3827 & 0.2087 \\
\hline $\mathrm{Se}^{2} / \mathrm{sr}^{2}$ & $53.52 \%$ & $100 \%$ & $100 \%$ & $17.77 \%$ & $17.66 \%$ & $15.61 \%$ & $100 \%$ \\
\hline Chi-square calculated value & 7.4741 & 8.5126 & 1.1650 & 90.0867 & 107.5883 & 102.5244 & 5.1867 \\
\hline Chi-square table value & 7.815 & 12.592 & 11.070 & 24.996 & 28.869 & 24.996 & 11.070 \\
\hline
\end{tabular}

Table 3.

Subgroup analysis CSR forms and dimensions

\begin{tabular}{|c|c|c|c|c|c|c|}
\hline \multirow[b]{2}{*}{ Description } & \multicolumn{3}{|c|}{ Developing countries } & \multicolumn{3}{|c|}{ Developed countries } \\
\hline & Labor & Social & Environ & Labor & Social & Environ \\
\hline$K$ & 4 & 4 & 4 & 6 & 5 & 8 \\
\hline$N$ & 394 & 394 & 394 & 1534 & 1359 & 1804 \\
\hline$\check{r}$ & 0.2177 & 0.2667 & 0.2042 & 0.1612 & 0.1920 & 0.1832 \\
\hline MinConf & 0.1172 & 0.2104 & 0.1750 & -0.0638 & -0.0815 & -0.0563 \\
\hline MaxConf & 0.3181 & 0.3229 & 0.2334 & 0.3861 & 0.4656 & 0.4227 \\
\hline $\mathrm{Se}^{2} / \mathrm{sr}^{2}$ & 100 & $58.56 \%$ & 100 & $12.02 \%$ & $8.71 \%$ & $11.90 \%$ \\
\hline Chi-square calculated value & 0.8685 & 6.8310 & 2.8614 & 49.9009 & 57.4286 & 67.2183 \\
\hline Chi-square table value & 7.815 & 7.815 & 7.815 & 11.070 & 9.488 & 14.067 \\
\hline
\end{tabular}

Table 4.

Subgroup analysis CSR forms and dimensions of developing and developed countries 
The Chi-square calculated value of the three dimensions of CSR in developing countries is smaller than the Chi-square table value, which infers a homogeneous relationship between CSR and FP. The subgroup analysis in the developing countries also produces a significant relationship between CSR and FP. The mean correlation of the labor dimension $(0.2177)$ is between the interval values of 0.1172 and 0.3181 , the mean correlation of the social dimension $(0.2667)$ is between the intervals of 0.2104 and 0.3229 and the mean correlation of the environmental dimension (0.2042) is between the intervals of 0.1750 and 0.2334 .

In developed countries, the subgroup analysis shows that the relationship between CSR and $\mathrm{FP}$ remains heterogeneous in the three dimensions. The explanatory power of the observed variance is less than $15 \%$ in the three dimensions. Studies of the three dimensions in developed countries also show that the relationship between CSR and FP is not significant. The mean correlation of the three dimensions falls between positive and negative confidence intervals (Table 4).

\subsection{Analysis subgroup - CSR measurement strategies}

Subgroup analysis based on CSR measurements maps five measurement strategies: content analysis (13 studies), reputation (25 studies), surveys (9 studies), social audits (7 studies) and principles and values (1 study). As the principles and values grouping only mapped one study, the subgroup analysis will not produce conclusions that have a better generalization. Therefore, the analysis is only carried out on the other four measurement strategies (Table 5). Subgroup analysis of the reputation and survey strategies yielded a significant relationship with a mean correlation of 0.2393 and 0.3689 , respectively, between confidence intervals. Meanwhile, content analysis and social audit strategies did not produce a significant relationship between CSR and FP, because the confidence intervals of the two dimensions had negative values.

Differences in subgroup analysis findings prove that CSR measurement strategies strengthen or weaken the relationship between CSR and FP. Thus, the fourth hypothesis is proven that CSR measurement strategies moderate the relationship between CSR and FP. Subgroups based on CSR measurement strategies do not increase the homogeneity of CSR and FP relationships because of the low explanatory power of the observed variants, which is less than $20 \%$ in the four CSR measurement strategies (Table 5).

\subsection{Subgroup analysis - FP measurement strategies}

The subgroup analysis based on the FP measurement strategies is presented in Table 6 . Significant results were found in three measurement groups: 1) accounting measurement strategy with a mean correlation of 0.2588 and a confidence interval of $0.0061-0.5116$; 2) market measurement strategy with a mean correlation of 0.3831 and a confidence interval of $0.0436-0.7227$; and 3 ) perception measurement strategy with a mean correlation of 0.3788 and

\begin{tabular}{lccrr}
\hline Description & Content analysis & Reputation & Survey & Social audit \\
\hline$K$ & 13 & 25 & 9 & 7 \\
$N$ & 1518 & 6413 & 1788 & 1338 \\
$\check{r}$ & 0.2129 & 0.2393 & 0.3689 & 0.1940 \\
MinConf & -0.0232 & 0.0287 & 0.1783 & -0.0813 \\
MaxConf $^{2} / \mathrm{sr}^{2}$ & 0.4489 & 0.4500 & 0.5595 & 0.4692 \\
Chi-square calculated value $_{\text {Chi-square table value }}^{17.91 \%}$ & $12.52 \%$ & $14.95 \%$ & $10.98 \%$ \\
& 72.5887 & 199.6465 & 60.2034 & 63.7391 \\
\end{tabular}

Relationship of CSR and financial performance

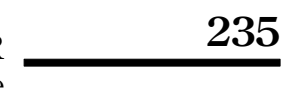


JABES 27,3

\section{6}

a confidence interval of $0.3554-0.4021$. However, the perception measurement strategy only consisted of three studies. Hence, the results could not be interpreted properly. An insignificant result was found in the combined measurement strategy subgroup with a very low average correlation (0.1461), and the confidence interval had a negative value ( -0.2965 to $0.5886)$, as shown in Table 6.

Differences in the results of the analysis of the four FP measurement strategies prove that the FP measurement strategy strengthens or weakens the relationship between CSR and FP. Therefore, the fifth hypothesis is proven: FP measurement strategies moderate the relationship between CSR and FP. However, the subgroup, based on the FP measurement strategy, shows a heterogeneous relationships for three measurement strategies: accounting, market and combination. The explanatory power of the observed variance is less than $15 \%$, and the Chi-square calculated value is much higher than the Chi-square table value for the three FP measurement strategies.

The perception measurement strategy subgroup increases the homogeneity of the relationship between CSR and $\mathrm{FP}$, as the Chi-square table value is above the Chi-square calculated value. However, there are only three studies in perception measurement strategies. In a small number of studies, only tentative conclusions can be made regarding the homogeneity of the relationships (Ahmed and Courtis, 1999).

\subsection{Discussion}

The results of the analysis reveal a positive relationship between CSR and FP. The metaanalysis generates multisetting conclusions so that this finding has broad generalizability. The results of this study address the inconsistencies of previous research results regarding the relationship between CSR and FP (McWilliam and Siegel, 2001; Brammer and Millington, 2008). The heterogeneity of the relationship between CSR and FP confirms the complexity of the natural characteristics of the relationship (Valiente et al., 2012) due to the institutional factors' differences (Zheng et al., 2014).

The difference in the relationship between CSR and FP in developed and developing countries is caused by differences in the institutionalization process in the two country characteristics. The tendency of MNCs in developing countries to imitate the CSR practices of parent companies in developed countries (Husted and Allen, 2006; Beddewela and Hezig, 2013) indicates that mimetic isomorphism is dominant in these countries. CSR in developing countries generally reflects the agenda of MNCs to differ from fulfilling their responsibility to the local communities (Wiig and Kolstad, 2010). Stakeholders in developing countries are often less aware of corporate CSR (Mellahi and Wood, 2003). This explains the insignificant relationship between CSR and FP in developing countries.

In developed countries, institutionalization of CSR practices occurs through coercive isomorphism. Strong institutional factors (e.g. law enforcement) in developed countries are

Table 6.

Subgroup analysis FP measurement strategies

\begin{tabular}{lcccc}
\hline Description & Accounting & Market & Combination & Perception \\
\hline$K$ & 40 & 13 & 22 & 3 \\
$N$ & 6362 & 2281 & 5756 & 770 \\
$\check{r}$ & 0.2588 & 0.3831 & 0.1461 & 0.3788 \\
Min Conf & 0.0061 & 0.0436 & -0.2965 & 0.3554 \\
Max Conf & 0.5116 & 0.7227 & 0.5886 & 0.4021 \\
$\mathrm{Se}^{2} / \mathrm{Sr}^{2}$ & $13.29 \%$ & $7.35 \%$ & $4.47 \%$ & $66.88 \%$ \\
$\mathrm{Chi}^{2}$-square calculated value & 271.3463 & 176.9459 & 492.6431 & 4.4859 \\
Chi-square table value & 54.572 & 21.026 & 32.671 & 5.991 \\
\hline
\end{tabular}


more prominent than in developing countries (Mishra and Suar, 2010; Jamali and Mirshak, 2007), which leads to more intensive CSR practices (Park et al., 2014; Baughn et al., 2007). However, normative isomorphism also occurs in developed countries; this is driven by companies' awareness that CSR practices benefit companies. In developed countries, CSR practices have been managed as a corporate strategy (Mullerat, 2013). This explains the significant relationship between CSR and FP in developed countries.

The various forms and dimensions of CSR explain the differences in the relationship between CSR and FP. Philanthropy activities are relatively easy to communicate to stakeholders and improve a company's reputation more immediately compared to other CSR forms and dimensions (Wang and Qian, 2011; Muller and Kräussl, 2011). This explains the significant relationship between CSR and FP on philanthropy dimension. CG issues caught the public's attention when the scandals of large companies unfolded (e.g. Enron). The stakeholder paradigm shifts to the importance of CG as part of CSR (Jamali et al., 2008). The issuance of various government regulations on $\mathrm{CG}$ and the birth of various $\mathrm{CG}$ institutions resulted in increased public attention toward CG.

This study shows that social, labor and environmental issues are vulnerable issues in developing countries (Visser, 2009). Labor cases, environmental pollution problems and the conditions of the surrounding communities affected by company operations are issues that often occur in the countries. Meanwhile, in developed countries with better legal instruments, the environmental, labor and social issues have been handled well. These issues have been considered to be the company's fundamental obligations, which must be carried out (Krukowska, 2014). This explains why the relationship of CSR with FP is significant in developing countries while insignificant in developed countries.

This study reveals the importance of objective CSR measurements in analyzing the relationship between CSR and FP. The relationship between CSR and FP is positive with an objective CSR measurement strategy. Content analysis and measurement of social audit show an insignificant relationship between CSR and FP while reputation and survey strategies generate a significant relationship between CSR and FP.

Furthermore, this study shows the importance of consensus regarding FP measurement in analyzing the relationship between CSR and FP. The analysis of the relationship between CSR and FP has a limited measurement method (Brammer and Millington, 2008). The study shows that the accounting, market and perception measurement strategies reveal a positive relationship between CSR and $\mathrm{FP}$, while the combination measurement strategy does not reveal a significant relationship. The lack of consensus regarding the performance measurement has led to a very inconsistent relationship between CSR and FP (Waddock and Graves, 1997).

\section{Conclusion}

The results of the meta-analysis conclude that aggregately CSR improves FP. The conclusion from this multisetting analysis has broad generalization power and is best used while making corporate strategies to improve FP. This study proves that the complexity of the relationship between CSR and FP is naturally given and suggests that the analysis of the relationship between CSR and FP includes institutional factors to produce generalizable conclusions. Country characteristics, forms and dimensions of CSR, CSR measurements and FP measurements explain the complexity of the relationship between CSR and FP.

Further research is suggested to expand the analysis of institutional factors to find other variables so that a homogeneous relationship between CSR and FP can be obtained. It is suggested that future research conduct subgroup analysis based on industry characteristics and the CG model. Differences in industry characteristics influence the choice of CSR forms and dimensions, providing the potential to be a factor that can influence the relationship 
JABES 27,3

between CSR and FP. The CG model adopted by developing countries and developed countries also has the potential to be an institutional factor to cause differences in the relationship of CSR and FP in both country characteristics.

\section{References}

Afiff, S. and Anantadjaya, S.P.D. (2013), “CSR \& performance: any evidence from Indonesian LQ45?”, Review of Integrative Business \& Economics Research, Vol. 2 No. 1, pp. 85-101.

Aguinis, H., Edwards, J.R. and Bradley, K.J. (2017), "Improving our understanding of moderation and mediation in strategic management research", Organizational Research Methods, Vol. 20 No. 4, pp. 665-685.

Ahmed, K. and Courtis, J.K. (1999), "Associations between corporate characteristics and disclosure levels in annual report: a meta-analysis", British Accounting Review, Vol. 31 No. 1, pp. 35-61.

Alexander, G.J. and Buchholz, R.A. (1978), "Corporate social responsibility and stock market performance", Academy of Management Journal, Vol. 21 No. 3, pp. 479-486.

Allouche, J. and Laroche, P. (2005), "A meta-analytical investigation of the relationship between corporate social and financial performance", Revue de Gestion des Resources Humaines, Vol. 57 No. 2005, pp. 18-41.

Asraf, M., Khan, B. and Tariq, R. (2017), "Corporate social responsibility impact on financial perfomance of bank's: evidence of Asian countries", International Journal of Academic Research in Business and Social Science, Vol. 7 No. 4, pp. 618-632.

Aver, B. and Cadez, S. (2009), "Management accountants participation in strategic managementprocesses: a cross industry comparisons", Journal for East European Management Studies, Vol. 14 No. 3, pp. 310-322.

Awan, A.G. and Saeed, S. (2015), "Impact of CSR on firm's financial perfomance: a case study of ghee and fertilizer industry in southern Punjab - Pakistan", European Journal of Business and Management, Vol. 7 No. 7, pp. 375-384.

Baughn, C., Bodie, N. and McIntosh (2007), "Corporate social and environmental responsibility in asian countries and other geographical regions", Corporate Social Responsibility and Environmental Management, Vol. 14 No. 4, pp. 189-205.

Beddewela, E. and Herzig, C. (2013), "Corporate social reporting by MNCs subsidiaries in Sri Lanka”, Accounting Forum, Vol. 37 No. 2, pp. 135-149.

Brammer, S. and Millington, A. (2008), "Does it pay to be different? An analysis of the relationship between corporate social and financial performance", Strategic Management Journal, Vol. 29 No. 12, pp. 1325-1343.

Brammer, S., Brooks, C. and Pavelin, S (2006), "Corporate social performance and stock returns: UK evidence from disaggregate measures”, Financial Management, Vol. 35 No. 3, pp. 97-116.

Brammer, S., Jackson, G. and Matten, D. (2012), "Corporate social responsibility and institutional theory: new perspectives on private governance”, Socio-Economic Review, Vol. 10 No. 1, pp. 3-28.

Carroll, A.B. (1979), "A three dimensional conceptual model of corporate social performance", Academy of Management Review, Vol. 4 No. 4, pp. 497-505.

Cheung, Y.L., Tan, W., Ahn, H.J. and Zhang, Z. (2010), "Does corporate social responsibility matter in Asian emerging markets?”, Journal of Business Ethics, Vol. 92 No. 3, pp. 401-413.

Choi, T.H. and Jung, J. (2008), "Ethical commitment, financial performance, and valuation: an empirical investigation of Korean companies", Journal of Business Ethics, Vol. 81 No. 2, pp. 447-463.

Clemens, E.S. and Cook, J.M. (1999), "Politics and institutionalism: explaining durability and change", Annual Review of Sociology, Vol. 25 No. 1999, pp. 441-466.

Crisóstomo, V.L., Freire, F.S. and Vasconcellos, F.C. (2011), "Corporate social responsibility, firm value, and financial perfomance in Brazil", Social Responsibility Journal, Vol. 7 No. 2, pp. 295-309. 
Dacin, M.T., Goodstein, J. and Scott, W.R. (2002), "Institutional theory and institutional change: introduction to the special research forum", Academy of Management Journal, Vol. 45 No. 1, pp. 45-57.

Deephouse, D.L. and Carter, S.M. (2005), "An examination of differences between organizational legitimacy and organizational reputation”, Journal of Management Studies, Vol. 42 No. 2, pp. 2322-2380.

DiMaggio, P.J. and Powell, W.W. (Eds) (1991), The New Institutionalism in Organisational Analysis, The University of Chicago Press, Chicago.

Dragomir, V.D. (2010), "Environmentally sensitive disclosures and financial performance in European setting", Journal of Accounting and Organizational Change, Vol. 6 No. 3, pp. 359-388.

Elsayed, K. and Paton, D. (2005), "The impact of environmental performance on firm performance: static and dynamic panel data evidence", Structural Change and Economic Dynamics, Vol. 16 No. 2005, pp. 395-412.

Fauzi, H., Mahoney, L.S. and Rahman, A.A (2007), "The link between corporate social performance and financial performance: evidence from Indonesian companies", Issues in Social and Environmental Accounting, Vol. 1 No. 1, pp. 149-159.

Fernandez, M.R. (2016), "Social responsibility and financial performance, the role of good corporate governance", Business Research Quarterly, Vol. 19 No. 2016, pp. 137-151.

Fernando, S. and Lawrence, S. (2014), "A theoretical framework for CSR practices: integrating legitimacy theory, stakeholder theory and institutional theory", The Journal of Theoretical Accounting, Vol. 10 No. 1, pp. 149-178.

Filbeck, G. and Gorman, R.F.(2004), "The relationship between the environmental and financial performance of public utilities", Environmental and Resource Economics, Vol. 29 No. 2004, pp. 137-157.

Finckh, A. and Tamer, M.R. (2008), "Primer: strengths and weaknesses of meta-analysis", Nature Clinical Practice Rheumatology, Vol. 4 No. 3, pp. 146-152.

Fiori, G., Donato, F.D.D. and Izzo, M.F (2007), "Corporate social rersponsibility and firms perfomance an analysis on Italian listed companies", available at: http://ssrn.com/abstract=1032851.

Galant, A. and Cadez,S. (2017), "Corporate social responsibility and financial performance relationship: a review of measurement approaches”, Economic Research-Ekonomska Istraživanja, Vol. 30 No. 1, pp. 676-693.

Garay, L. and Font, X. (2012), "Doing good to do well? Corporate social responsibility reasons, practices and impacts in small and medium accommodation enterprises", International Journal of Hospitality Management, Vol. 31 No. 2012, pp. 329-337.

Godfrey, P.C. (2005), "The relationship between corporate philanthropy and shareholder wealth: a risk management perspective”, Academy of Management Review, Vol. 30 No. 4, pp. 777-798.

Goll, I. and Rasheed, A.A. (2004), "The moderating effect of environmental munificence and dynamism on the relationship between discretionary social responsibility and firm performance", Journal of Business Ethics, Vol. 49 No. 1, pp. 41-54.

Golrida, K.P., Subroto, B., Sutrisno, T. and Saraswati, E. (2018), "The complexity of relationship between corporate social responsibilityy (CSR) and financial performance", Emerging Markets Journal, Vol. 8 No. 2, pp. 19-25.

Griffin, J.J. and Mahon, J.F. (1997), "The corporate social performance and corporate financial performance debate", Business and Society, Vol. 36 No. 1, pp. 5-31.

Grigoris, G. (2016), "The challenges of corporate social responsibility assessment methodologies", International Journal in Economics and Business Administration, Vol. 4 No. 1, pp. 39-55.

Halme, M. and Laurila, J. (2009), "Philanthropy, integration or innovation? Exploring the financial and societal outcomes of different types of corporate responsibility", Journal of Business Ethics, Vol. 84 No. 3, pp. 325-339.

Huang, S.K. and Yang, C.L. (2014), "Corporate social performance: why it matters? Case of Taiwan”, Chinese Management Studies, Vol. 8 No. 4, pp. 704-716.
Relationship of CSR and financial performance 
JABES 27,3

Hogan, K., Olson, G.T. and Sharma, R. (2014), "The role of corporate philanthropy on ratings of corporate social responsibility and shareholder return", Journal of Leadership, Accountability and Ethics, Vol. 11 No. 3, pp. 108-126.

Hunter, J.E. and Schmidt, F.L. (1990), Methods of Meta-Analysis: Correction Error and Bias in Research Findings, Sage, Beverly Hills, CA.

Husted, B.W. and Allen, D.B. (2006), "Corporate social responsibility in the multinational enterprise: strategic and institutional approaches", Journal of International Business Studies, Vol. 37 No. 6 , pp. 838-849.

Inoue, Y. and Lee, S. (2011), "Effects of different dimensions of corporate social responsibility on corporate financial performance in tourism-related industries", Tourism Management, Vol. 32 No. 2011, pp. 790-804.

Jamali, D. and Mirshak, R. (2007), "Corporate social responsibility (CSR): theory and practice in a developing country context", Journal of Business Ethics, Vol. 72 No. 3, pp. 243-262.

Jamali, D., Safieddine, A.M. and Rabbath, M. (2008), "Corporate governance and corporate social responsibility synergies and interrelationships", Corporate Governance, Vol. 16 No. 5, pp. 443-459.

Jamali, H., Sutrisno, T., Subekti, I. and Assih, P. (2015), "The influence of corporate governance and corporate social responsibility on financial performance with efficiency as mediating variable", International Journal of Business and Management Invention, Vol. 5 No. 4, pp. 1-10.

Jang, J.I., Lee, K. and Choi, H.S. (2013), "The relation between corporate social responsibility and financial performance: evidence from Korean firms”, Pan Pacific Journal of Business Research, Vol. 4 No. 2, pp. 3-17.

Jhon, E.A., Jhon, A.O. and Adedayo, O.E. (2013), "Corporate social responsibility and financial performance: evidence from Nigerian manufacturing sector", Asian Journal of Management Research, Vol. 4 No. 1, pp. 153-162.

Jones, T. (1995), "Instrumental stakeholder theory: a synthesis of ethics and economics", Academy of Management Review, Vol. 20 No. 2, pp. 404-437.

Kamatra, N. and Kartikaningdyah, E. (2015), "Effect corporate social responsibility on financial performance", International Journal of Economics and Financial Issues, Vol. 5 No. 2015, pp. 157-164.

Kang, K.H., Lee, S. and Huh, C. (2010), "Impacts of positive and negative corporate social responsibility activities on company performance in the hospitality industry", International Journal of Hospitality Management, Vol. 29 No. 2010, pp. 72-82.

Kanwal, M., Khanam, F., Nasreen, S. and Hameed, S. (2013), "Impact of corporate social responsibility on the firm's financial performance", IOSR Journal of Business and Management (IOSR-JBM), Vol. 14 No. 5, pp. 67-74.

Karagiorgos, T. (2010), "Corporate social responsibility and financial performance", European Research Studies, Vol. 13 No. 4, pp. 86-108.

Krukowska, M. (2014), "Determinants of corporate social responsibility in Japanese companies", Management and Business Administration Central Europe, Vol. 22 No. 4127, pp. 39-57.

Lee, S. and Park, S.Y. (2010), "Financial impacts of socially responsible activities on airline companies”, Journal of Hospitality \& Tourism Research, Vol. 34 No. 2, pp. 185-203.

Lee, S., Singal, M. and Kang, K.H. (2013), "The corporate social responsibility - financial perfomance link in the U.S. restaurant industry: do economic conditions matter?”, International Journal of Hospitality Management, Vol. 32 No. 2013, pp. 2-10.

Li, S., Fetscherin, M., Alon, I., Lattemann, C. and Yeh, K. (2010), "Corporate social responsibility in emerging markets: the importance of the governance environment", Management International Review, Vol. 50 No. 5, pp. 635-654.

Lin, C.H., Yang, H.L. and Liou, D.Y. (2009), "The impact of corporate social responsibility on financial perfomance: evidence from business in Taiwan”, Technology in Society, Vol. 31 No. 2009, pp. 56-63. 
Luo, X. and Bhattacharya, C.B. (2006), "Corporate social responsibility, customer satisfaction, and market value", Journal of Marketing, Vol. 70 No. 4, pp. 1-18.

Macdonald, J.B. and Maher, M. (2013), "The relationship between equity dependence and environmental performance", Journal of Leadership, Accountability and Ethics, Vol. 10 No. 2, pp. 35-45.

Mahoney, L. and Roberts, R.W. (2007), "Corporate social perfomance, financial perfomance and institutional ownership in Canadian firms", Accounting Forum, Vol. 31 No. 2007, pp. 233-253.

Makni, R., Francoeur, C. and Bellavance, F. (2009), "Causality between corporate social performance and financial performance: evidence from Canadian firms", Journal of Business Ethics, Vol. 89 No. 3, pp. 409-422.

McWilliams, A. and Siegel, D. (2001), "Corporate social responsibility: a theory of the firm perspective", The Academy of Management Review, Vol. 26 No. 1, pp. 117-127.

Mellahi, K. and Wood, G. (2003), "The role and potential of stakeholders in hollow participation", Business and Society Review, Vol. 108 No. 2, pp. 183-202.

Menguc, B. and Ozanne, L.K. (2005), "Challenges of the green imperative: a natural resource- base approach to the environmental orientation - business perfomance relationsip", Journal of Business Research, Vol. 58 No. 2005, pp. 430-438.

Meyer, J.W. and Rowan, B. (1977), "Institutionalized organizations: formal structure as myth and ceremony", American Journal of Sociology, Vol. 83 No. 2, pp. 340-363.

Michelon, G., Boesso, G. and Kumar, K. (2013), "Examining the link between strategic corporate social responsibility and company performance: an analysis of the best corporate citizens", Corporate Social Responsibility Environmental Management, Vol. 20 No. 2013, pp. 81-94.

Mishra, S. and Suar, D. (2010), "Does corporate social responsibility influence firm performance of Indian companies?”, Journal of Business Ethics, Vol. 95 No. 4, pp. 571-601.

Muller, A. and Kräussl, R. (2011), "The value of corporate philanthropy during times of crisis: the sensegiving effect of employee involvement”, Journal of Business Ethics, Vol. 103 No. 2, pp. 203-220.

Mullerat, R. (2013), “Corporate social responsibility: a European perspective”, The Jean Monnet/Robert Schuman Paper Series, Vol. 13 No. 6, pp. 1-22.

Mwangi, C.I. and Jerotich, O.J. (2013), "The relationship between corporate social responsibility practices and financial performance of firms in the manufacturing, construction and allied sector of the Nairobi securities exchange", International Journal of Business, Humanities and Technology, Vol. 3 No. 2, pp. 81-90.

Namazi, M. and Namazi, N.R. (2016), "Conceptual analysis of moderator and mediator variables in business research", Procedia Economics and Finance, Vol. 36 No. 2016, pp. 540-554.

Oeyono, J., Samy, M. and Bampton, R. (2011), “An examination of corporate social responsibility and financial performance a study of the top 50 Indonesian listed corporations", Journal of Global Responsibility, Vol. 2 No. 1, pp. 100-112.

Orlitzky, M., Schmidt, F.L. and Rynes, S.L. (2003), "Corporate social and financial performance: a metaanalysis”, Organization Studies, Vol. 24 No. 3, pp. 403-441.

Park, B. II and Ghauri, P.N. (2015), "Determinants influencing CSR practices in small and medium sized MNE subsidiaries: a stakeholder perspective", Journal of World Business, Vol. 50 No. 1, pp. 192-204.

Park, B. II, Chidlow, A. and Choi, J. (2014), "Corporate social responsibility: stakeholders influence on MNEs' activities”, International Business Review, Vol. 23 No. 5, pp. 966-980.

Peloza, J. (2009), "The challenge of measuring financial impacts from investments in corporate social performance", Journal of Management, Vol. 35 No. 6, pp. 1518-1541.

Rettab, B., Brik, A.B. and Mellahi, K. (2009), "A study of management perceptions of the impact of corporate social responsibility on organisational performance in emerging economies: the case of dubai”, Journal of Business Ethics, Vol. 89 No. 3, pp. 371-390.
Relationship of CSR and financial performance 
JABES 27,3

Saeidi, S.P., Sofian, S., Saeidi, P., Saeidi, S.P. and Saaeidi, S.A. (2014), "How does corporate social responsibility contribute to firm financial performance? The mediating role of competitive advantage, reputation, and customer satisfaction”, Journal of Business Research, Vol. 68 No. 2014, pp. 341-350.

Schreck, P. (2011), "Reviewing the business case for corporate social responsibility: new evidence and analysis", Journal of Business Ethics, Vol. 103 No. 2, pp. 167-188.

Seo, C.J., Min, K.Y. and Chongwoo, C. (2010), "Corporate social responsibility and corporate financial performance: evidence from Korea”, Munic Personal Repec Archive Paper No. 22159, available at: http://mpra.ub.uni-muenchen.de/22159.

Surroca, J., Tribo, J.A. and Waddock, S. (2010), "Corporate responsibility and financial performance: the role of intangible resources", Strategic Management Journal, Vol. 31 No. 5, pp. 463-490.

Torugsa, N.A., O'Donohue, W. and Hecker, R. (2012), "Capabilities, proactive CSR and financial perfomance in SME's: empirical evidence from an Australian manufacturing industry sector", Journal of Business Ethics, Vol. 109 No. 2012, pp. 483-500.

Uadiale, O.M. and Fagbemi, T.O. (2012), "Corporate social responsibility and financial performance in developing economies: the Nigerian experience", Journal of Economics and Sustainable Development, Vol. 3 No. 4, pp. 44-55.

Valiente, J.M.A., Ayerbe, C.G. and Figueras, M.S. (2012), "Social responsibility practices and evaluation of corporate social performance", Journal of Cleaner Production, Vol. 35 November, pp. 25-38.

Visser, W. (2009), "Corporate social responsibility in developing countries", in Book the Oxford Handbook of Corporate Social Responsibility, Oxford University Press, Oxford.

Waddock, S.A. and Graves, S.B. (1997), "The corporate social performance - financial performance link", Strategic Management Journal, Vol. 18 No. 4, pp. 303-320.

Wang, H. and Qian, C. (2011), "Corporate philanthropy and corporate financial performance: the roles of stakeholder response and political access", Academy of Management Journal, Vol. 54 No. 6, pp. 1159-1181.

Wei, Y.C. and Lin, C.Y.Y. (2015), "How can corporate social responsibility lead to firm performance? A longitudinal study in Taiwan”, Corporate Reputation Review, Vol. 18 No. 2, pp. 111-127.

Wiig, A. and Kolstad, I. (2010), "Multinational corporations and host country institutions: a case study of CSR activities in Angola", International Business Review, Vol. 19 No. 2, pp. 178-190.

Wolfe, R. and Aupperle, K. (1991), "Introduction to corporate social performance: methods for evaluating an elusive construct", in Post, L.E. (Ed.), Research in Corporate Social Performance and Policy, JAI Press, Greenwich, CT, Vol. 12 No. 1991, pp. 265-268.

Yang, F.J., Lin, C.W. and Chang, Y.N. (2010), "The linkage between corporate social performance and corporate financial perfomance", African Journal of Business Management, Vol. 4 No. 4, pp. 406-413.

Yusoff, W.F.W. and Adamu, M.S. (2016), "The relationship between corporate social responsibility and financial performance: evidence from Malaysia”, International Business Management, Vol. 10 No. 4, pp. 345-351.

Yusoff, H., Mohamad, S.S. and Darus, F. (2013), "The influence of CSR disclosure structure on corporate financial performance: evidence from stakeholders' perspectives", Procedia Economics and Finance, Vol. 7 No. 2013, pp. 213-220.

Zheng, Q., Luo, Y. and Maksimov, V. (2014), "Achieving legitimacy through corporate social responsibility: the case of emerging economy firms", Journal of World Business, Vol. 687 No. 2014, pp. 1-15. 


\begin{tabular}{|c|c|c|c|c|c|c|c|}
\hline & Sample & $\mathrm{Ni}$ & ri & Ni.ri & Countries & Criteria & perfo \\
\hline 1 & Afiff and Anantadjaya (2013) & 104 & 0.5474 & 56.9296 & Indonesia & Deving & \\
\hline 2 & Babalola, Yisau Abiodun & 100 & -0.0226 & -2.2608 & Nigeria & Deving & \\
\hline 3 & Brammer et al. (2006) & 451 & 0.4500 & 202.9500 & United Kingdom & Dev & 243 \\
\hline 4 & Fauzi et al. (2007) - ROA & 383 & 0.0083 & 3.1783 & Indonesia & Deving & \\
\hline 5 & Fiori (2007) - Stock Price & 75 & 0.1586 & 11.8958 & Italy & Dev & \\
\hline 6 & Garay and Font (2012) & 319 & 0.3990 & 127.2810 & Spain & Dev & \\
\hline 7 & Hogan et al. (2014) & 540 & 0.3438 & 185.6610 & No specific (NS) & & \\
\hline 8 & Cheung et al. (2010) & 1188 & 0.1938 & 230.1812 & Asian emerging & Deving & \\
\hline 9 & Dragomir (2010) & 60 & 0.0185 & 1.1100 & European & Dev & \\
\hline 10 & Elsayed and Paton (2005) & 227 & 0.1293 & 29.3587 & United Kingdom & Dev & \\
\hline 11 & Filbeck and Gorman (2004) & 22 & 0.7333 & 16.1334 & NS & & \\
\hline 12 & Huang and Yang (2014) & 71 & 0.3490 & 24.7790 & Taiwan & Dev & \\
\hline 13 & Inoue and Lee (2011)- Restaurant & 74 & 0.7145 & 52.8730 & NS & & \\
\hline 14 & Inoue and Lee (2011)- Airline & 59 & -0.1585 & -9.3515 & NS & & \\
\hline 15 & Inoue and Lee (2011) - Casino & 51 & 0.2765 & 14.1015 & NS & & \\
\hline 16 & Inoue and Lee (2011) - Hotel & 183 & 0.0160 & 2.9280 & NS & & \\
\hline 17 & Jang et al. (2013) & 130 & 0.2263 & 29.4233 & Korea & Dev & \\
\hline 18 & Kang et al. (2010) - Hotel & 44 & 0.3461 & 15.2284 & NS & & \\
\hline 19 & Kang et al. (2010) - Restaurant & 58 & 0.0365 & 2.1170 & NS & & \\
\hline 20 & Kang et al. (2010) - Casino & 132 & 0.5045 & 66.5940 & NS & & \\
\hline 21 & Kang et al. (2010) - Airline & 60 & -0.1118 & -6.7050 & NS & & \\
\hline 22 & Lee and Park (2010) & 46 & -0.1548 & -7.1221 & NS & & \\
\hline 23 & Lee et al. (2013) & 226 & 0.1840 & 41.5840 & US & Dev & \\
\hline 24 & Lin et al. (2009) & 33 & 0.1464 & 4.8313 & Taiwan & Dev & \\
\hline 25 & Mahoney and Roberts (2007) & 352 & 0.3550 & 124.9600 & Canada & Dev & \\
\hline 26 & Makni et al. (2009) & 179 & 0.0667 & 11.9333 & Canada & Dev & \\
\hline 27 & Muller and Kräussl (2011) & 125 & 0.1880 & 23.5000 & NS & & \\
\hline 28 & Oeyono et al. (2011) & 48 & 0.1715 & 8.2320 & Indonesia & Deving & \\
\hline 29 & Rettab et al. (2009) & 280 & 0.3000 & 84 & $\begin{array}{l}\text { United Arab } \\
\text { Emirates }\end{array}$ & Dev & \\
\hline 30 & Saeidi et al. (2014) & 205 & 0.6729 & 137.9357 & Iran & Deving & \\
\hline 31 & Seo et al. (2010) & 1122 & 0.3533 & 396.4400 & Korea & Dev & \\
\hline 32 & Torugsa et al. (2012) & 171 & 0.4700 & 80.3700 & Australia & Dev & \\
\hline 33 & Uadiale and Fagbemi (2012) & 40 & 0.8855 & 35.4200 & Nigeria & Deving & \\
\hline 34 & Wei and Lin (2015) & 175 & 0.2700 & 47.2500 & Taiwan & Dev & \\
\hline 35 & Yang et al. (2010) & 150 & 0.1163 & 17.4500 & Taiwan & Dev & \\
\hline 36 & Crisóstomo et al. (2011) & 296 & -0.1400 & -41.4400 & Brazil & Deving & \\
\hline 37 & Fernandez (2016) & 107 & 0.3490 & 37.3412 & Spain & Dev & \\
\hline 38 & Schreck (2011) & 294 & 0.0693 & 20.3742 & NS & & \\
\hline 39 & Wang et al. (2011) & 114 & 0.1990 & 22.6860 & China & Deving & \\
\hline 40 & Yusoff et al. (2013) & 57 & 0.3951 & 22.5180 & Malaysia & Deving & \\
\hline 41 & Misrah and Suar (2010) & 150 & 0.4100 & 61.5000 & India & Deving & \\
\hline 42 & Luo and Bhattacharya (2006) & 339 & 0.1350 & 45.7650 & NS & & \\
\hline 43 & Choi and Jung (2008) & 248 & 0.1696 & 42.0608 & Korea & Dev & \\
\hline 44 & Menguc and Ozanne (2005) & 140 & 0.2000 & 28 & Australia & Dev & \\
\hline 45 & Michelon et al. (2013) & 188 & 0.5450 & 102.4600 & NS & & \\
\hline 46 & Surroca et al. (2010) & 696 & 0.0700 & 48.7200 & NS & & \\
\hline 47 & Karagiorgos (2010) & 78 & 0.4230 & 32.9973 & Greece & Dev & \\
\hline 48 & Awan and Saeed (2015) & 100 & 0.5904 & 59.0400 & Pakistan & Deving & \\
\hline 49 & Kanwal et al. (2013) & 75 & 0.4300 & 32.2500 & Pakistan & Deving & \\
\hline & & & & & & (continued) & $\begin{array}{r}\text { Table A1. } \\
\text { Sample description }\end{array}$ \\
\hline
\end{tabular}




\begin{tabular}{|c|c|c|c|c|c|c|c|}
\hline \multirow{5}{*}{$\begin{array}{l}\text { JABES } \\
27,3\end{array}$} & & Sample & $\mathrm{Ni}$ & ri & Ni.ri & Countries & Criteria \\
\hline & 50 & $\begin{array}{l}\text { Kamatra and Kartikaningdyah } \\
\text { (2015) }\end{array}$ & 76 & 0.1806 & 13.7292 & Pakistan & Deving \\
\hline & 51 & Mwangi and Jerotich (2013) & 50 & 0.5380 & 26.9000 & Nairobi & Deving \\
\hline & 52 & Yusoff and Adamu (2016) & 100 & 0.4375 & 43.7500 & Malaysia & Deving \\
\hline & 53 & Jamali et al. (2015) & 297 & 0.1650 & 49.0048 & Indonesia & Deving \\
\hline \multirow{2}{*}{244} & 54 & Asraf et al. (2017) & 102 & -0.0382 & -3.8913 & NS & \\
\hline & 55 & Jhon et al. (2013) & 100 & 0.4180 & $\begin{array}{r}41.8000 \\
\end{array}$ & Nigeria & Deving \\
\hline Table A1. & & Effect size & 11.090 & & & 2746.7552 & 477 \\
\hline
\end{tabular}

\section{Corresponding author}

Golrida Karyawati P can be contacted at: golridda@yahoo.com

For instructions on how to order reprints of this article, please visit our website:

www.emeraldgrouppublishing.com/licensing/reprints.htm

Or contact us for further details: permissions@emeraldinsight.com 